\title{
The future of sustainable urbanism: a redefinition
}

\author{
Rob Roggema ${ }^{1,2^{*}}$ (D)
}

\begin{abstract}
In this article the future of sustainable urbanism is discussed. In current times a complex of uncertainties demands sustainable environments. Three uncertainties are distinguished. Firstly, the city needs to deal with uncertain developments, such as the impacts of climate change. Secondly, urban environments are the place where deliberate uncertainties, such as the generation of renewable energy and other sustainability transitions must find a place. The third form of uncertainty is the increased exposure of urban populations to the impacts of a spectrum of uncertain developments, climate impacts. This 'Triple-U problem' urges the design of urban areas to be sustainable. Sustainability has long been a part of urbanism, however, in completely different ways in different periods in history. When learning from the past, the analysis of sustainable urbanism in seven periods brings key elements to the fore. Sustainable urbanism has evolved, but key characteristics of each period may and can still be used to design sustainable cities. Based on these characteristics two strategies, and a potential third one, are identified: to fix the future, to indulge the future, and to create anti-fragile urban environments. Where fixing the future implies the reparation of environmental qualities and closing environmental flows within the urban boundaries, indulging the future focuses on the creation of sufficient space to accommodate the possible spatial impacts of unprecedented events and change. Anti-fragility supports the city in raising its resilience under threat of uncertain impacts. The article ends with a proposed renewed definition of sustainable urbanism.
\end{abstract}

Keywords: Sustainable urbanism, Future of cities, Anti-fragility, Uncertainty

\section{Background}

Since the 'Brundtland report' (World Commission on Environment and Development 1987) sustainable development is a main goal for many sectors in urban policy-making. This has also impacted the practices and theories of urbanism. Over the years, this led to many frameworks, concepts and planning principles. One often noticed outcome of this goal is the Freiburg Charter (Daseking et al. 2012), in which the principles are defined in three groups: spatial development, content and process. These principles provide guidelines on how a sustainable city can be developed.

Sustainable urbanism is defined as "walkable and transit-served urbanism integrated with high performance

\footnotetext{
*Correspondence: rob@cittaideale.eu

${ }^{1}$ Faculty of Design, Architecture and Building, University of Technology Sydney, Ultimo, Sydney, Australia

Full list of author information is available at the end of the article
}

buildings and high-performance infrastructure" (Farr 2007). A more broad definition is: "the application of sustainability and resilient principles to the design, planning, and administration/operation of cities" (Sharifi 2016). Compactness (density) and biophilia (human access to nature) are considered as the core values of sustainable urbanism (Adhya et al. 2011). Others question compactness as being really sustainable (Daneshpour and Shakibamanesh 2011; Neuman 2005). In practice, the ten leaders in urban sustainability each have their own thematic focus area: transport in Bogota, energy in Melbourne, air quality in Mexico City and so on (Schwartz 2013). Hence the main focus of sustainable urbanism lies on the design of urban environments and aims to implement sustainable solutions through these designs. The leading cities however show strong preference for certain themes.

In order to become sustainable cities need to adopt a new approach to planning the city. In the World Cities 
Report (UN Habitat 2016) this is described as the city that plans in contrast to the planned city. The 'city that plans' uses integrated and multi-sectored planning approaches, takes into account local circumstances and involves diverse populations including women, plans are prepared at different geographical scales and across political boundaries, and improves the education for planners, especially in developing countries. A city that plans not only projects the future from past trends, it also brings the public, private and third sectors together with communities to build a collectively preferred future. These aspects of planning don't seem ground-breaking, but in many cities they are not applied. The following principles are defined to support implementation: promote sustainable development, achieve integrated planning, integrate plans with budgets, plan with partners and stakeholders, meet the subsidiarity principle, promote market responsiveness, ensure access to land, develop appropriate planning tools, be pro-poor and inclusive, and recognize cultural diversity (Farmer et al. 2006). The New Urban Agenda aims to harness the potential of cities and human settlements to help eradicate poverty in all its forms and dimensions, reduce inequalities, promote inclusive growth, and achieve sustainable development (Habitat III 2016). Hence it provides a new global framework to develop sustainable cities. One of the principles defined is to 'transform the way we plan, develop, govern and manage cities and human settlements, recognizing sustainable urban development as an essential instrument to achieve prosperity for all and sustainable development.'

In this article firstly the problem with current policymaking in the field of sustainable urbanism will be examined. Secondly, sustainable urbanism is looked at from a historic perspective, the development of this field is analysed and gaps and threats for developing sustainable cities in the future are identified. This article ends with a suggested new definition of sustainable urbanism, which resembles future requirements.

\section{Problem: 'triple U'}

In the introduction many initiatives, frameworks, policy documents are mentioned, which all aim to make cities more sustainable. Besides the ones mentioned above there are many more. Still, the majority of these frameworks are somewhat problematic, because they focus on intervening in planning, policy-making and decisionmaking at a certain moment in time. Given the known facts, the city should take measures to increase the level of sustainability. This leads, at its best, to a sustainable city in a given year: when the measures come into effect.

In the meantime, many aspects that influence life on earth, and especially in cities, are changing, surprise us and are unprecedented. In these frameworks there's only limited awareness that uncertainties will impact cities more than these planning frameworks can deal with. We distinguish three types of uncertainty:

- Uncertain developments Many developments themselves are uncertain. Especially topics such as climate change, but also migration and technological developments are wicked problems (Rittel and Webber 1973; VROM-raad 2007; Commonwealth of Australia 2007) and hard to predict.

- Enforced uncertainties Several sustainability transitions, such as the transition towards a green economy (Allen and Clouth 2012) or a low-carbon energy supply (Foxon et al. 2010; Bulkeley et al. 2010) are deliberately enforced, which change the system. In order to accommodate these transitions the city itself needs to transform.

- Exposure to uncertainties The urbanisation of global population continues (UN 2008) and most of the cities worldwide are located in vulnerable locations (Kreimer et al. 2003) hence the number of people that will have to deal with these uncertainties is rapidly increasing.

When these uncertainties are combined a triple uncertainty ('triple U') emerges: uncertain developments + deliberate transitions + increase of urban population. Moreover, not only are cities located at vulnerable places, they are also the places where all these uncertainties collide. And, in order to stay the place where the majority of global people live, the city should be developed in a sustainable way. The combinations of uncertainties cause a complexity, which gives reason to redefine the concept of sustainable urbanism. Before we do, we look at the evolution of this concept over time.

\section{Evolution of sustainable urbanism}

Looking back in time, sustainability has not always been a central theme in urbanism. The famous image of the architect eating the landscape, by Malcolm Wells, illustrates the way urbanism was seen for a long time: as a destroyer of natural values. Girardet (1996) was one of the first to acknowledge the importance of an integrated approach to developing cities in a sustainable way. $\mathrm{He}$ connected themes such as looking at cities as ecosystems, the footprint of cities, urban heat islands, and others with urban design schools, such as the garden city movement (Howard 1902), the modern city of Le Corbusier (Cohen and Benton 2008), Frank Lloyd Wright's Broadacre city (Wise 2013) and megacities in general (Nicholls 1995; Donatiello 2015). His pledge for convivial cities the role of citizens and the local scale and the attention for health, greening the city, renewable energy and recycling, and 
sustainable forms of mobility, are still relevant. Since then many perspectives, visions and conceptual practices have been developed, each of them taking sustainability into account in planning and designing cities in one way or another.

Seven distinctive periods show how the concept of sustainability has evolved over time.

\section{Aesthetics}

For a long time men dominated nature and aesthetic rules determined the design of cities, buildings and gardens. Geometry and symmetry were important tools for design, through which the environments of man and nature could be separated. Landscapes were mostly arranged according to strict rules. The Italian landscape architects, such as illustrated by looking at the Villa d'Este, Tivoli (Lazzaro 1990) and architects, such as Vitruvius (Vitruvii 1480) and Palladio (Wundram and Pape 1988) represented the attention for beauty as an important factor of sustainability in this period. Vitruvius described what the key values for a good architectural or urban design should be: firmitas, utilitas and venustasthat is, it must be solid, useful, beautiful (Kriens et al. 2008).

Beautiful (venustas) is the value of how something is experienced: 'A measure for the experiential function. (...) beauty, when the appearance of the work is pleasing and in good taste, and when its members are in due proportion according to correct principles of symmetry'.

Solid (firmitas) describes the future value. This 'regards the degree to which use and experiential values are futuredirected. (...) Durability will be assured when foundations are carried down to the solid ground and materials wisely and liberally selected.

Useful (utilitas) is a value that is' a measure for the use function, and as such depends on the perspective one takes. The use value of spatial objects depends on the urban system they are part of. (...) convenience, when the arrangement of the apartments is faultless and presents no hindrance to use, and when each class of building is assigned to its suitable and appropriate exposure.

Later, these values have been redefined for designing and planning the landscape (Ministerie van Landbouw, Natuur en Visserij 1992). A landscape (or a city for that matter) should be:

- Aesthetically valuable (experience the origins, potential for orientation, beauty).

- Ecologically valuable (de amount of variation, coherence and environmental quality).

- Economically valuable (a just and sustainable economic-utility basis for different land-uses).
Urban sustainability is defined as a multi-layered concept and aesthetics is equally important as economic viability or ecological value, not more or less important. Sustainability is not similar to environmental quality. A high environmental quality only does not guarantee a high sustainability. Similarly, an urban environment with a high environmental quality or a high economic value, but without beauty is also not sustainable.

\section{Rationalism}

In a second period sustainable urbanism is characterised by the assumption that knowledge is the crucial driver in design and that knowledge will implicitly lead to solutions. An expert planner or the designer "who knows it all' (Gunder 2011) is required to translate this knowledge into functional urban environments. The shape of the city follows the land use, or 'form follows function' (Sullivan 1896), and engineers play an important role in the final outcome of the design process. The design is to be a measurable outcome of functional ingredients and necessities. This has led to, for instance in the Netherlands, rationally and artificially designed landscapes, such as the Noordoostpolder area (Fig. 1), and urban designs, such as Pendrecht in Rotterdam, that were inspired by Mondrians and Van Doesburgs artworks, such as the paintings 'Composition with Yellow, Blue, and Red' (Mondrian) and 'Composition VII, the three graces' (Van Doesburg). An almost literal use of 'the Rhythm of a Russian Dance', painted by van Doesburg in 1918, led to Van den Broek and Bakema's design for the Alexanderpolder neighbourhood in Rotterdam.

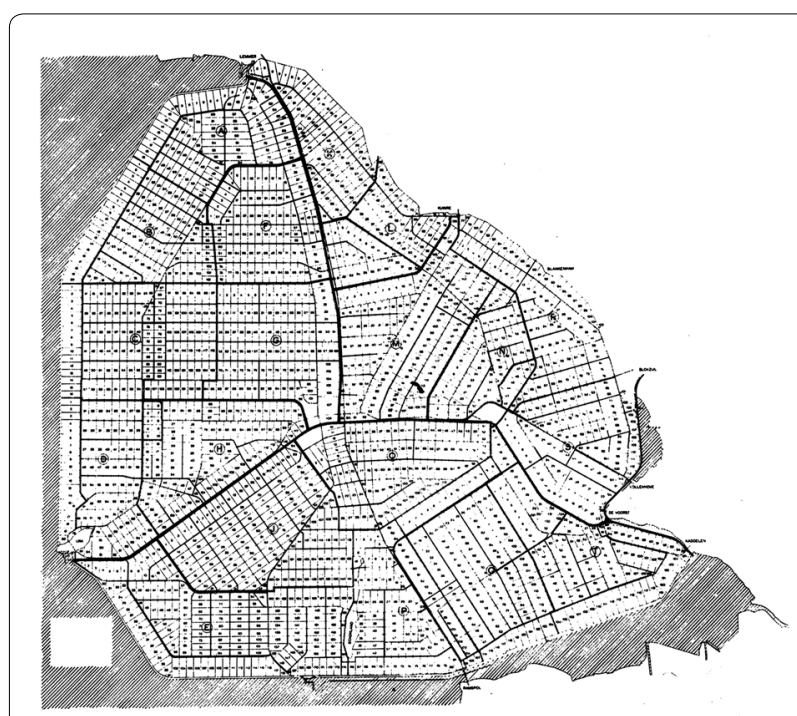

Fig. 1 Layout of the Noordoostpolder design. Source: https://beeldbank.rws.nl, Rijkswaterstaat/Afdeling Multimedia Rijkswaterstaat 
This orderly way of thinking implies that there is a clear distinction between city and countryside. The rational program of the city differs radically from the program in its surrounding landscape. In all areas rationalism translates a quantitative program into designs. In this context sustainability presents itself as a quantifiable aspect by introducing all kinds of standards and regulations, such as for clean water, air and soil.

\section{Conceptualism}

In this third period the design of concepts, or concepts inspiring designs, is at the core. Ecological understanding of the water system, the soil and nature becomes important as the directing force of these concepts. This is reflected in concepts that use layers to analyse the different spatial elements. Based on the work of McHarg (1969), this 'layer-approach' is widely used in the Netherlands (Van Schaick and Klaasen 2011). This analytical instrument distinguishes an abiotic, a biotic and an anthropogenic layer, which, integrated, shape the landscape. This concept is also used in policy-making and planning. Since 2001 the Dutch national government uses the approach to identify planning opportunities, using slightly different layers: subsoil, networks and occupation. It assumes the occupation patterns are nested in the infrastructure networks, which, in turn are embedded in the substrate system (Priemus 2007). The layers aim to separate different dynamics of use. Where the subsoil is seen as changing extremely slowly, and the networks change at a moderate pace, the occupation patterns can change relatively rapidly. Based on this thinking the casco-concept was developed, a spatial manifestation of how different spatial dynamics are separated (Sijmons 1992). The lower dynamics in the landscape, such as nature and water form the casco, within which higher dynamic uses, such as agriculture, find their space. For urban areas a similar concept is developed. The two networks strategy links higher dynamic uses (traffic, industries, intensive forms of agriculture) to the transportation network and the lower dynamic uses (nature, green, water, residential) and to the water network (Tjallingii 1995, 2015; Fig. 2). These types of concepts are used to design urban and rural plans and to locate the different land-uses.

\section{Negotiatism}

In this period sustainability is seen as a negotiable aspect. In order to make sustainable development discussable, different ambitions are defined, which can be negotiated during the planning process. Once a certain ambition is set, it is easy to check whether the plan has delivered the expected level of sustainability. New methods are developed to target sustainability ambitions, such as the

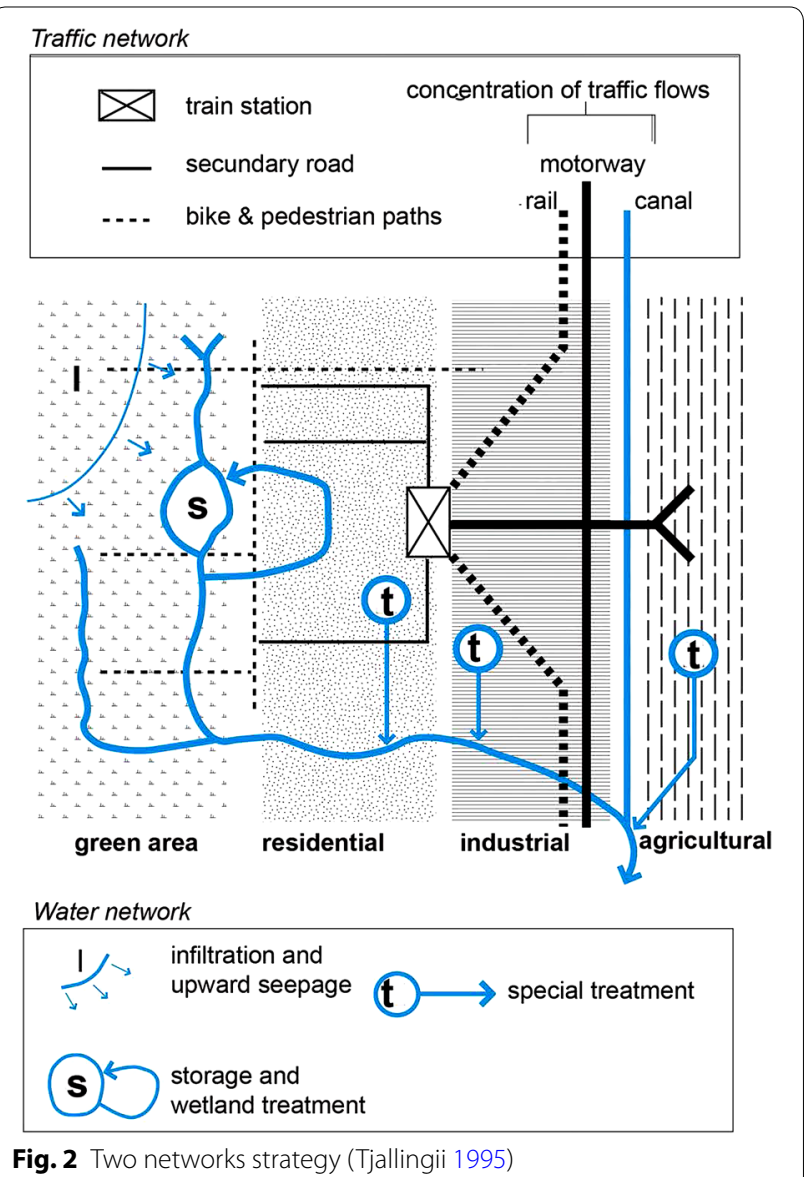

DCBA-method (Teeuw 2010), in which for every aspect, ecology, water, green, traffic, materials etc. requirements are set for level A to D which are aimed to be realised in the plan. Often this method is welcomed by politicians, who would like to choose a certain level, show their ambitions and in hindsight can be accountable. At a later stage this thinking formed the basis for many checklists and building codes, such as LEED or BREEAM. Sustainability is seen as an external factor to the planning process, which has to be pushed forward and legitimised by a standard, which can easily be encapsulated in the planning or design of a building or (part of) a city. This type of external integration was very useful when sustainability still needed to claim its spot in spatial and urban developments. It enabled communities to discuss their desired level of sustainability.

Where this firstly led to large conversation sessions without a lot of designing, over time it evolved into more advanced participatory planning processes, in which engaged citizens could discuss the sustainability of their direct environment (Roggema et al. 2014a, b). In these sessions the wisdom of the crowd (Surowiecki 2004) is 
used to identify future strategies for a sustainable spatial development.

Recently a development of co-creation (Sanders and Stappers 2008) becomes visible, in which citizens, together with governments and industries collaborate in problem identification, design of solutions and realisation.

\section{Systemism}

In this period the city, and its surroundings are seen as an ecosystem (Tomásek 1979). In this concept resources can enter the system and rest-flows are exhausted. The system itself is capable of regulating in- and outgoing resource flows and the processes of using, reusing and transforming these resources. When the layer approach is combined with this systems thinking a comprehensive model for urban environmental design (Kristinsson 2012) emerges (Fig. 3). Within the system networks are taken as the basis for design. The degree to which the system is able to deal with the flows, or networks, of traffic, water, energy and materials, determines the level of sustainability of the system.

Starting from the premise of the city as a system, sustainable urbanism aims to close the loop by eliminating environmental impact of urban development by providing all resources locally. It looks at the full life cycle of the products to make sure that everything is made sustainably, and sustainable urbanism also brings things like electricity and food production into the city. This means that literally everything that the town or city needs is right there making it truly self-sufficient and sustainable. Green urbanism delivers a conceptual model for zeroemission and zero-waste urban design (Lehmann 2010). This urban metabolism (Wolman 1965; Newman 1999; Kennedy et al. 2007; Kennedy et al. 2010; Shafiea et al. 2013) describes the city in flows and aims to reduce the use of resources, to process them as efficiently as possible and to reduce the waste flows. Hence, when the city is able to close the cycles within its boundaries, a sustainable situation is achieved. However, when thinking in terms of systems, the boundaries of a city become fuzzy, a Zwischenstadt (in between city) emerges (Sieverts 1997) and the countryside and the city become one (Timmermans et al. 2015). The land use is determined by negotiation, interests of particular parties and land prices and to a lesser extent by planning. An urban tapestry evolves (Heynen 1990), in which several land uses are spread over the area seemingly illogically. However, looking at it from the perspective of the underlying systems the location of things is actually very logical: the city evolved from a clear city centre, hosting all services, via a compact city, with services as closely as possible to the centre to a city of flows, connected through networks with specialised places for specific services.

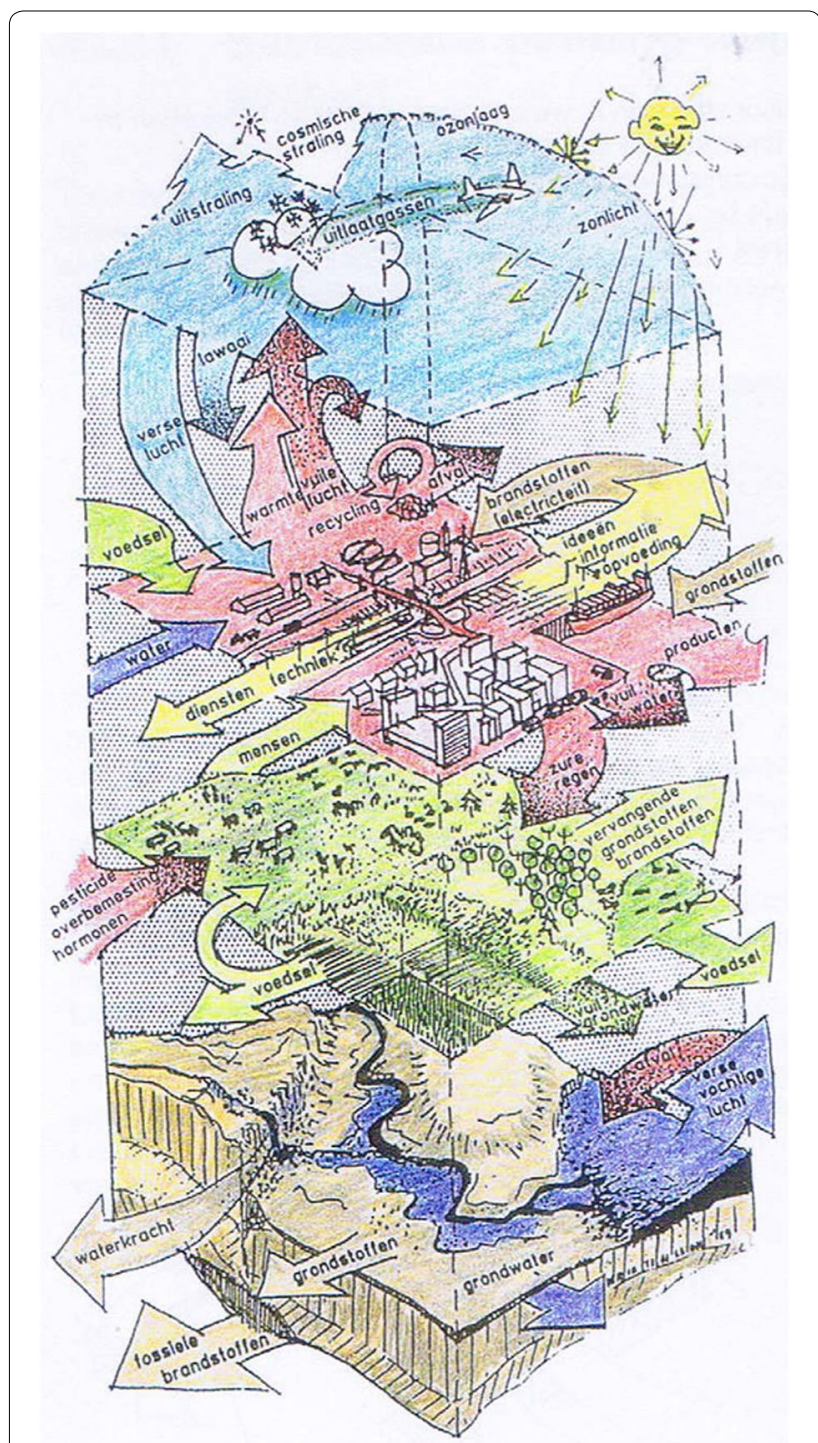

Fig. 3 The environmental urban model (Kristinsson 2012)

To get a grip on developments the design of cities leans on the understanding of networks and flows. The design of the city is then based on ways in which depletion of resources and production of waste are reduced and in which resources can be reused and recycled within the city (Fig. 4). Several studies within the Urban by Nature Biennale (Brugmans and Strien 2014) have shown how to design the flows in a city, such as the study for Rotterdam has revealed (Tillie et al. 2014).

\section{Emergism}

Directly linked to systemism, the period of emergism focuses on the adaptive capacities of complex systems. Complexity theory (Prigogine and Stengers 1984; Mitchell Waldrop 1992; Kauffman 1993, 1995; Cohen and Stewart 


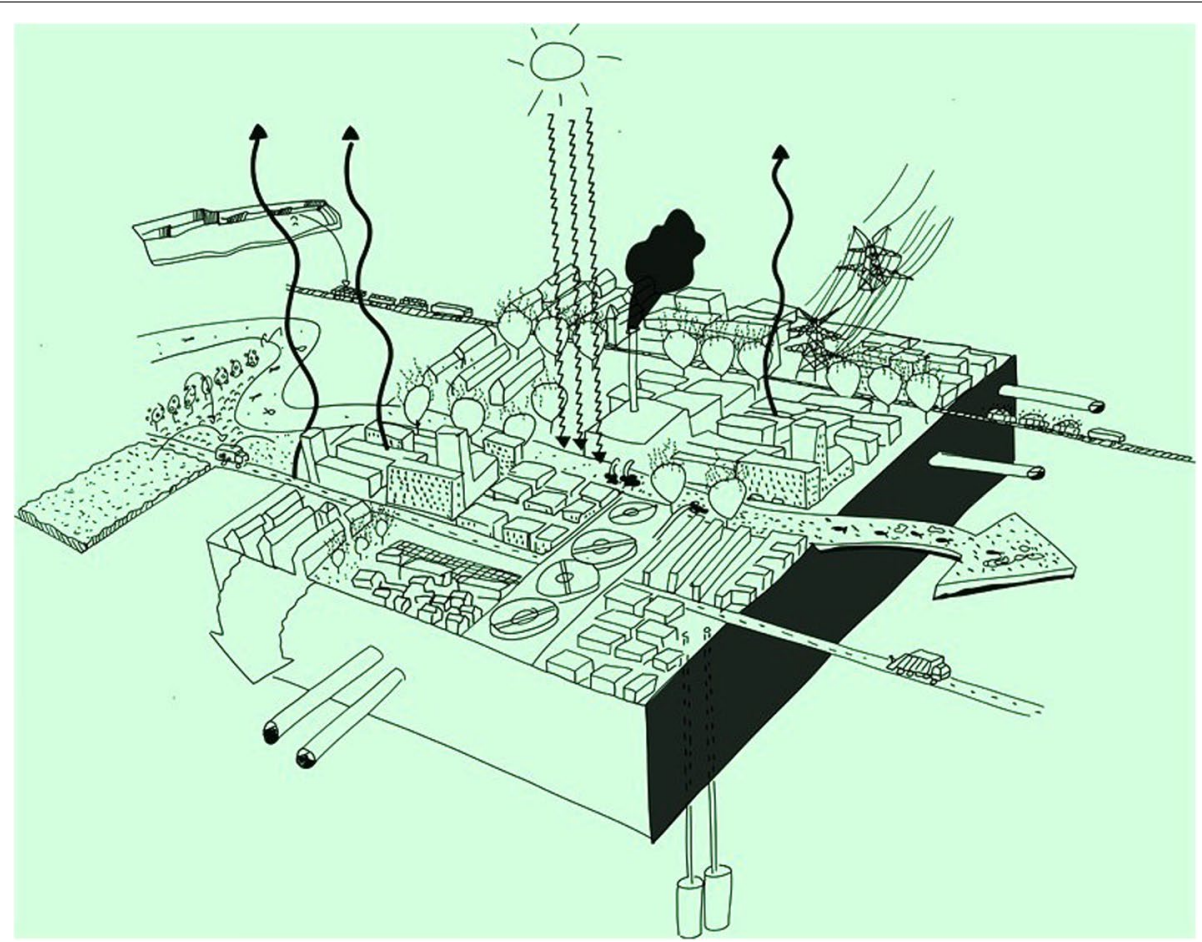

Fig. 4 Urban metabolism model. Source: Dirk Sijmons/Jutta Raith, H + N + S Landschapsarchitecten, IABR-2014 Urban by Nature

1994) is taken as the input for the design of cities (Portugali 2000; Roggema 2012a). Understanding the adaptive capacity of systems helps to plan for cities that are more resilient. Self-organisation and emergence are key concepts and are used to design interventions in the system to achieve certain changes. These concepts are common in nature and can be used in designing future cities and landscapes that are more adaptable (Waterman 2010). The design for a climate proof Groningen (Roggema 2009) or the plans for the Sand Engine (Stive et al. 2013), both in the Netherlands, are good examples of building with nature.

In several urban and community contexts self-organising groups and organisations plan for their own environments outside the governmental, political arena and herewith create a disordered order of spaces that are 'becoming' (Newman 2011). Sometimes this self-organising power occurs in well-organised planning processes, as has been demonstrated in several design charrettes (Roggema et al. 2013; Roggema 2012b), but it can also be ignited in anarchistic ways of planning, like it happened at Tahrir-square in Cairo, Egypt (Roggema 2012c).

In this context the planner/designer acts as a facilitator of the process of change, intervening at specific places or times to initiate a change in the system. For instance, ecoacupuncture (Ryan 2013) aims to design multiple small interventions in an existing urban precinct to change the community's ideas of what is permissible, desirable and possible and provide transformation points for a new trajectory of development (Ryan et al. 2013). Similarly, Swarm Planning (Roggema 2012a) proposes a methodology to design landscapes for unexpected climate impacts through simple interventions, which direct the spatial system to become more resilient. In order to apply these principles physical elements in the city or the landscape need to be made moveable (Roggema 2014) and able to respond to different paces of change that might occur in the city: fast, slow or sudden (Roggema 2015). In order to adapt to new circumstances urban systems need to become agile (Russell 2011). The examples of watersquares in Rotterdam (Urbanisten 2013) and Copenhagen (Perry 2016) illustrate this increase in agility, as these squares change from a playground into a leisure pond or water basin in case of heavy rainfall.

\section{Anti-fragilism}

Rather than responding to change, urban sustainability could also be enhanced by creating urban environments that hold the capability to become stronger as result of responding to unprecedented future events. A system then is not only able to respond to changes in an agile way, but more than this, it is able to use these responses to make itself stronger and more capable of dealing with unexpected changes in the future. This concept is called anti-fragility (Taleb 2012) and it has not 
been used in urban design yet. However, this concept offers new insights in how urban environments could be treated in uncertain times. If the city could create a stronger flood defence by itself once a flood occurs, the city would be more safe than in the situation where the flood defence was built beforehand, but turns out not to meet the strength required. In hindsight the design for Hafencity in Hamburg (HafenCity Hamburg GmbH 2006), Germany is an example of an anti-fragile design. This area, under influence of periodical high water levels in the Elbe, is made capable of 'flipping' to a second ground level at the moment the water reaches higher levels. The lower levels in the area are prepared to overflow, and houses, parkings and other uses at the lower ground level can be hermetically closed off until the water level drops. This way the entire city becomes independent of rising water levels; it even becomes a stronger and more resilient environment than without the design solutions. In a regular design the Hafencity area would be closed off by a levee to protect the precinct behind it, creating a vulnerable, fragile situation, because in the instance the protection fails, the consequential damage is huge.

Anti-fragilism is no common approach yet. However, the current combination of increasing uncertainties and unalterable cityscapes means the risk of a growing number of places being under threat is rising. Therefore it is necessary to acknowledge the potential upcoming of a new wave in sustainable urbanism, and start research and practical applications in design projects.

\section{Linking concepts}

The concepts and approaches of sustainable urbanism shift over time (Fig. 5), with each concept and approach fitting the timeframe during which it was developed and used. Many of the concepts overlap and relics can be witnessed until today.

When the concepts are connected to each other and the strengths of each period are taken and integrated into sustainable urbanism, a new perspective emerges. The key qualities of each of the periods mentioned above are linked (Fig. 6), illuminating the integrated strength of sustainable urbanism. This constructed and comprehensive set of properties can be used for sustainable urban designs. Many current urban designs predominantly focus on one sustainability issue or approach. Therefore the set of capabilities can provide an integrated sustainable perspective on urban development, notwithstanding other important factors in city design, such as land values, programmatic aspects and others.

\section{Two strategies for sustainable urbanism}

In order to tackle the triple uncertainties two strategies will be distinguished here: the first is to fix the future and the second is to indulge the future. A third strategy, which seems to hold promises for the future, will be touched on here: anti-fragility. A more elaborate discussion of this strategy would require more elaborated research and is beyond the scope of this paper.

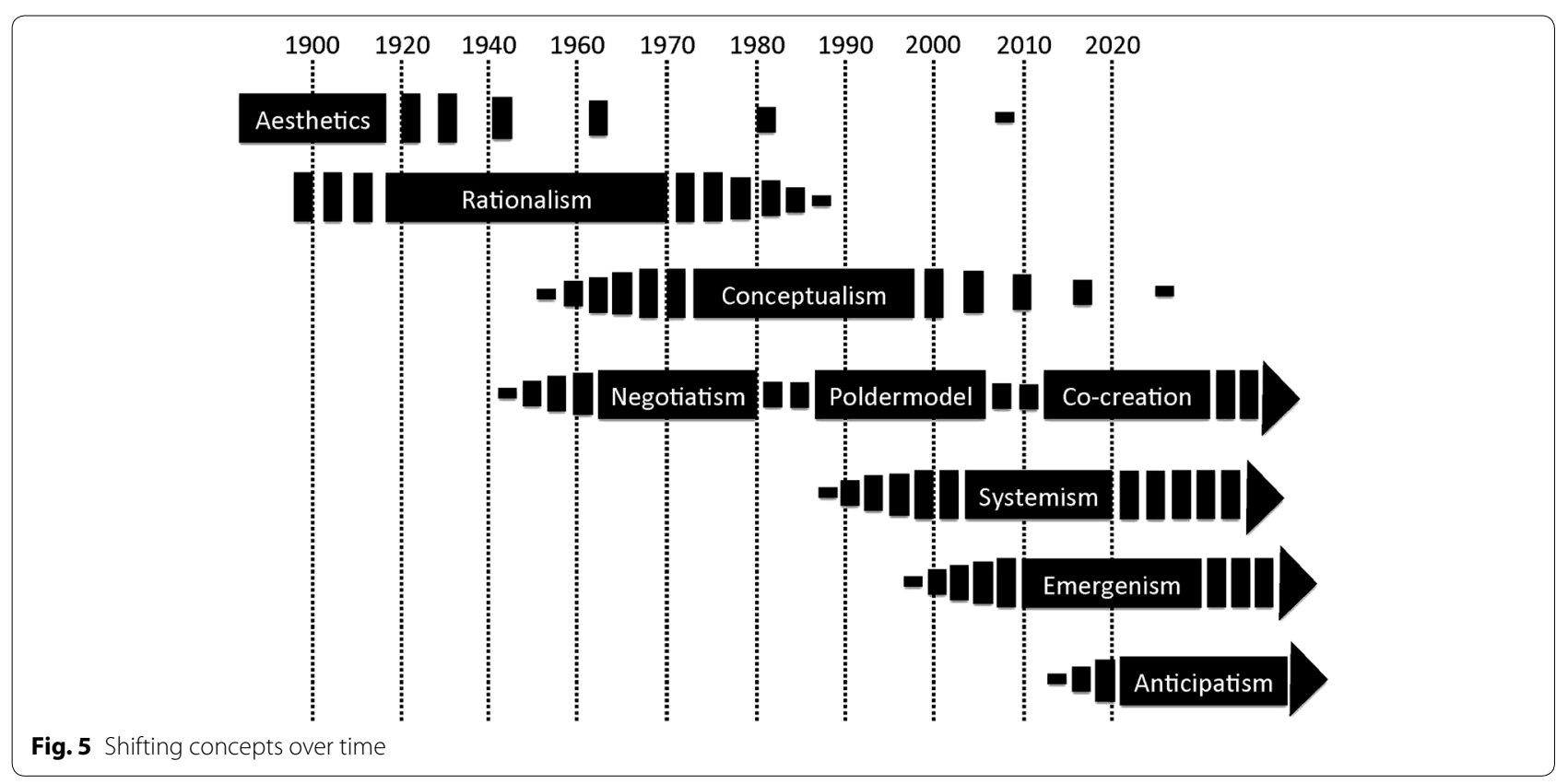




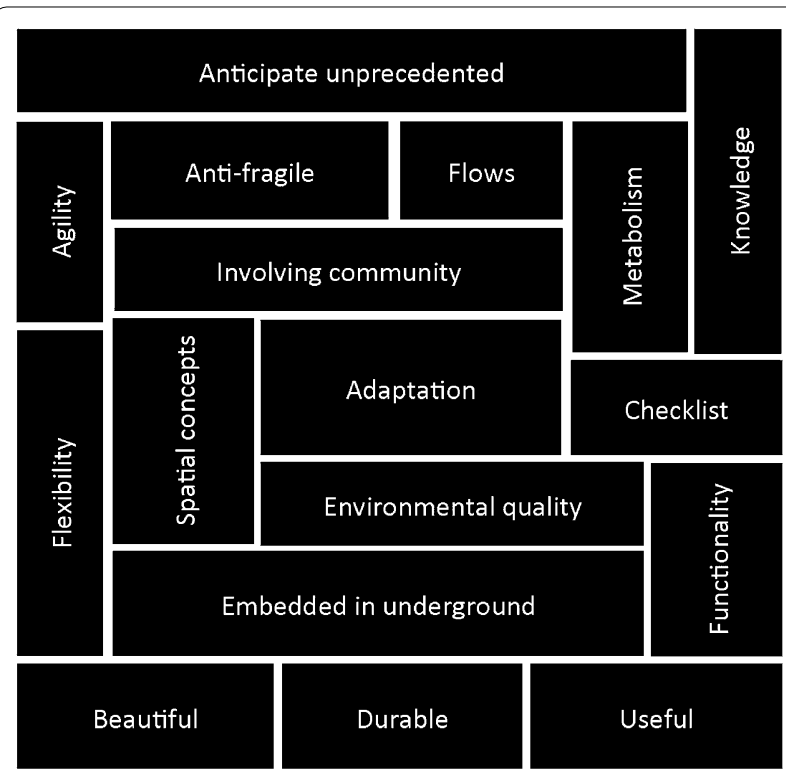

Fig. 6 The strengths of sustainable urbanism

\section{Fixing the future}

The strategy to fix the future aims to increase the environmental resilience of the urban environment. The future is repaired, even before it is lost. Through the application of urban design principles the loss of biodiversity, resources and environmental quality is limited and compensated for. In and around the city ecological water and green systems are implemented and renewable energy sources are cultivated or generated. The mobility is minimised and sustainable modes of transportation are implemented. In and around the urban settlements a range of food production is planned to provide the urban population with fresh, naturally produced crops.

The resources used and also the waste produced during processing and use in the city are minimised. An analysis of the diverse flows, which come into the city, are processed and re-used or put through the city and then leave the city again, gives insights in the amount and size of spaces required for these flows to be accommodated and treated, processed or distributed. This analysis and these insights, in combination with existing green and water spaces, forms the input and condition for designing a sustainable city.

There are many examples already of these so-called eco-cities or eco-villages designed and realised around the world, such as Morra Park in Drachten (Beatley 2000; Kristinsson 2012), Westerpark in Breda (Gemeente Breda 1993), EVA-Lanxmeer in Culemborg (Van Timmeren 2006; Van Timmeren et al. 2007), all in the Netherlands, Freiburg in Germany (Freytag et al. 2014), Hammarby in Sweden (Pandis Iverot and Brandt 2011), Tianjin in China
(Caprotti et al. 2015), the BedZED eco-village in London (Chance 2009), Matavenero in Spain (Drury 2015) and many others.

The mainstream definition of sustainable urbanism is along these lines of thinking: repairing the harm done to the natural system, recycle and reuse resources, and clean waste.

When the urban system is designed to foster sustainability in this way, new uncertain developments, such as the impacts of climate change, are hard to incorporate. When abundance of space is created for regeneration functions, green and water, urban agriculture and other 'environmental' functions, the chance is bigger this will satisfy the needs of unexpected changes. However, because these changes are inherently uncertain, the available space might be in the wrong place. In fact this may lead to an unsustainable situation in the future and adaptive urban management (Birkmann et al. 2010; Searns 1995; Gilmour et al. 1999) is required.

Enforced uncertainties are in principle easy to plan for. These new uses require space in urban areas, but if these transitions link up with sustainability principles, they are able to co-exist in the same areas. An example of this is the situation where windmills are combined with natural wetlands.

Locating new urban developments in vulnerable areas increases the exposure to uncertainties, hence this is not recommended as these spaces are required for creating the space to implement sustainability principles. For instance, building in the coastal zone minimises biodiversity, leaves less space for regeneration of the natural system (cleaning the water, etc.) and exposes more housing to the risk of flooding. This could be arranged through strict regional planning, but in practice this is often either not possible or planning directives are too weak to prevent urban occupation of these areas.

\section{Indulging the future}

The strategy of indulging the future aims to increase the spatial resilience in the city. In accommodating change urban form should be flexible and adaptable. Rather than creating fixed patterns, urban forms are allowed to emerge, the shape depending on external factors and change. For the urban environment to be open to change a systems approach is helpful. Complex, self-organising, adaptive systems, as cities are seen (Andersson 2012; Ikeda 2004; Bettencourt 2013, 2015; Batty 2013; Portugali 2000; Webster and Lai 2003; Roggema 2012a; De Roo et al. 2012; Portugali et al. 2012), have the capability to adapt to change. Self-organisation of the city, or the society of the city can be 'planned' by setting rules about the relation between built elements, being buildings, linear elements or district elements. These urban codes 
regulate how these elements relate to each other, informing planning in a qualitative way (Alfasi and Portugali 2007). Urban coding will generate an indirect order, e.g. a nomocratic approach), by creating a stable and simple set of abstract and general relational rules, which enable society itself to be highly flexible. Leaving options open for society. The problem of complexity and intrinsic unpredictability requires a radical overhaul of the tools used to regulate land-use-particularly by exploring the idea of shifting the emphasis to framework instruments, such as urban codes (Moroni 2015). Swarm planning (Roggema 2012a) suggests such a framework for dynamic environments, in which different paces of change are accommodated by different layers of planning, and planning starts with the biggest uncertainty or threat in mind. The impact of an intervention dealing with this uncertainty, creates a potential tipping point, which in turn regulates the spatial configuration of the future as it subsequently will be filled with spatial additions, and built elements by society. Moreover, when built elements of which the city is comprised become dismantable, the urban codes can be reinterpreted and the city may selforganise into new, best-fitting configurations. In order for this to happen, spaces, and also physical elements, have to be able to change over sometimes very short time periods. Open spaces and structures in the city, such as the green network, should be designed in such a way that they can expand and shrink in size or change land use whenever necessary (Roggema 2014). This is a new task for urbanism.

The strategy of indulging the future is very well equipped to deal with uncertain developments, as the designed system encapsulates the potential to anticipate and increase resilience when an unprecedented event occurs, for instance when the capacity, flexibility and agility of the urban system are increased, through creating spaces for temporary land use, or 'unused' open spaces.

Enforced uncertainties can be incorporated in the design, but these tend to fix certain uses for certain areas. For instance, once an area is in use for biomass production, it is difficult to temporarily change the use to accommodate a flood in the same area. The biomass harvest will fail.

Using the strategy to indulge the future, new, unused or temporary spaces will be created to accommodate sudden changes. When this is part of the regional design new urban areas will hardly be exposed to uncertainties. For instance, if an area is created along the coast for a sudden flood, this area will not be occupied by urban extensions and water could enter this place without destroying inhabited areas. However, if urban areas expand organically and anarchically, it is hard to keep areas free of occupation hence exposure of urban precincts to risks might increase.

When the two strategies are linked to the different forms of uncertainty (Table 1) it shows that neither of the two strategies is completely satisfactory. Hence, in order to truly design urban areas sustainably both strategies are required in conjunction.

\section{A potential third strategy: anti-fragility}

Besides fixing or indulging the future, there could be a third strategy to deal with the three forms of uncertainty. When a city not only fixes sustainability problems or transforms uncertainties to its advantage, but could also grow in strength and resilience when the impacts of an unprecedented event hit the city. This strategy of anti-fragility is creating places in the city where, once an unexpected change occurs, its responses to the change actually increase its resilience for the future. This concept is relatively new and requires more experimentation in design for the city, but looks like a promising strategy in supporting the city not only to bounce back after a sudden change or disaster has occurred, but also to 'bounce forward': to turn the negative impact into growing resilience at the same time.

\section{Redefining sustainable urbanism}

The approach to developing sustainable urban areas needs to consist of the two, and maybe three strategies mentioned before. It should accommodate both the need for regeneration of vital functions within the urban realm and, in parallel, the creation of enough flexibility in order to accommodate sudden changes of land use. Additionally it should create its urban environments in a way that makes them more resilient when something unexpected occurs. This triple-layered search for the sustainable and resilient city leads to a redefinition of sustainable urbanism:

"Design a sustainable urban system, which creates physical and mental space to adjust the urban form at any moment in time, anticipates uncertain, unexpected and unprecedented change, and grows stronger and becomes more resilient when uncertainty impacts on it".

This implies that in the city open spaces need to be created, which are not determined for one single use, where

Table 1 Potential of the two strategies to deal with the different uncertainties

\begin{tabular}{lll}
\hline & Fix the future & Indulge the future \\
\hline Uncertain developments & - & ++ \\
Enforced uncertainties & + & - \\
Exposure to uncertainties & 0 & + \\
\hline
\end{tabular}


adjustments over time are possible and flexibility in land use can be easily and instantly achieved. Urban areas should be able to not only change function, but also change shape, acting as a breathing organism. Sometimes the city inhales people, when population grows, and sometimes it exhausts them, in times of shrinkage. Similarly the city sometimes inhales water, in periods of heavy rain or a sudden flood, before slowly exhausting the water again. For many functions the city operates as a sponge, taking up and getting rid of materials, flows and organisms. In the urban design this requires the creation of spaces that are adjustable. At least $30 \%$ of the territory should be available for temporary use or able to change its use rapidly (Roggema 2012a, b, c; Roggema and Broess 2014a, b).

The following principles for urban design can be formulated:

- Allow for and regulate or code spaces for new, temporary or sudden use;

- Invent and design spaces that make the city stronger in case of a disaster;

- Create enough space for green, water, regeneration, both for people as the ecosystem;

- Allow for spaces where human and ecological demands for clean air, soil, water, sufficient food and energy and places to stay and live are integrated;

- Arrange the spaces and places such that cycles of materials, water, energy, food and mobility can be closed.

\section{Conclusion}

In this article sustainable urbanism is positioned as an approach to deal with different types of future uncertainty. The analysis of several periods highlighted the key elements of sustainable urbanism in the past. Together these characteristics can be used to develop sustainable urban areas from two perspectives and eventually lead to a redefinition of sustainable urbanism.

It can be concluded that the approach to create more sustainable cities is evolving and depends on the timeframe that is considered. Learning form each of the periods, the strengths can be combined and lead to a strong set of key elements for sustainable urbanism. This set can be applied in any urban design task.

Dealing with different forms of uncertainty, two perspectives on creating a sustainable city prove to be fruitful: firstly, increasing the regeneration function of cities, improving its environmental qualities and optimising urban metabolism, and secondly creating more space for unprecedented events, by which the city will become more adaptable to sudden change. To be adaptable it is necessary to think in the order of $30 \%$ of the total territory kept free of fixed uses.
Further research is required on how to integrate the two strategies in design propositions and include the potential third strategy of anti-fragility. Despite the fact that these strategies aim to increase sustainability in the city, the strategies do not necessarily strengthen each other. Design research could help to find the synergies and to design integrated spatial propositions.

Further research is also necessary on how these strategies work out at different scales, such as the regional, metropolitan, city, urban precinct and neighbourhood levels. How does a nested system of sustainability options work and how are the components at each scale related to each other? It is easy to calculate the metabolism for one flow at one scale, but how do several flows at several scales match, or work against each other? How to prevent problems to be passed on to other areas or to the future?

Finally, it would make sense to conduct new research on how truly anti-fragile urban environments can be designed. Which spatial interventions are capable of creating an area that will improve under threat of unprecedented change?

\section{Author details \\ ${ }^{1}$ Faculty of Design, Architecture and Building, University of Technology Sydney, Ultimo, Sydney, Australia. ${ }^{2}$ Louis Raemaekerslaan 13, 6709 TB Wagen- ingen, The Netherlands.}

\section{Competing interests}

The author declares that he has no competing interests.

Received: 16 September 2016 Accepted: 19 October 2016 Published online: 24 October 2016
References

Adhya A, Plowright P, Stevens J (2011) Defining sustainable urbanism: towards a responsive urban design. In: Proceedings of the conference on sustainability and the built environment. King Saud University, Saudi Arabia. 3-6 January 2010

Alfasi N, Portugali J (2007) Planning rules for a self-planned city. Plan Theory 6(2):164-182

Allen C, Clouth S (2012) A guidebook to the green economy. UNDESA, New York

Andersson DE (ed) (2012) The spatial market process. Emerald, Bingley Batty M (2013) A new science of cities. MIT Press, Cambridge

Beatley T (2000) Green urbanism; learning from European cities. Island Press, Washington DC

Bettencourt LM (2013) The origin of scaling in cities. Science 340:1438-1441

Bettencourt LM (2015) Cities as complex systems. In: Furtado BA (ed) Modeling complex systems for public policies. Spinger, Heidelberg

Birkmann J, Garschagen M, Kraas F, Quang N (2010) Adaptive urban governance: new challenges for the second generation of urban adaptation strategies to climate change. Sustain Sci 5(2):185-206

Brugmans G, Strien J (eds) (2014) IABR 2014—urban by nature. Idea books, Amsterdam

Bulkeley H, Broto VC, Hodson M, Marvin S (eds) (2010) Cities and low carbon transitions. Routledge, London

Caprotti F, Springer C, Harmer N (2015) 'Eco' for whom? envisioning ecourbanism in the Sino-Singapore Tianjin Eco-city, China. Int J Urban Reg Res 39(3):495-517

Chance T (2009) Towards sustainable residential communities; the Beddington zero energy development (BedZED) and beyond. Environ Urban 21(2):527-544. doi:10.1177/0956247809339007 
Cohen J-L, Benton T (eds) (2008) Le Corbusier Le Grand. Phaidon Press Limited, London

Cohen J, Stewart I (1994) The collapse of chaos: discovering simplicity in a complex world. Penguin Group Ltd, London

Commonwealth of Australia (2007) Tackling wicked problems; a public policy perspective. Australian government/Australian public service commission, Canberra

Daneshpour A, Shakibamanesh A (2011) The compact city; does it create an obligatory context for urban sustainability? Int J Archit Eng Urban Plan 21(2):110-118

Daseking W, Köhler B, Kemnitz G (2012) The Freiburg charter. Stadtplanungsamt, Freiburg

De Roo G, Hillier J, van Wezemael J (eds) (2012) Complexity and planning: systems, assemblages and simulations. Ashgate Publishing, Farnham

Donatiello JE (2015) The world's population: an encyclopedia of critical issues, crises, and ever-growing countries. Ref User Serv Q 54(4):85

Drury F (2015) Enchanting photos of the abandoned village taken over by hippies living in fairytale houses in the Spanish mountains. MailOnline, 1 July 2015. http://www.dailymail.co.uk/news/article-3139295/Enchanting-photos-abandoned-village-taken-Spanish-hippies-living-fairytalehouses-mountains.html. Accessed 5 Sept 2016

Farmer P, Frojmovic M, Hague C, Harridge C, Narang S, Shishido R, Siegel D, Taylor P, Vogelij J (2006) Reinventing planning: a new governance paradigm for managing human settlements. Position paper for debate leading into the World Planners Congress, Vancouver, 17-20 June, http://www.globalplannersnetwork.org/pdf/reinventingplanningenglish.pdf. Accessed 26 June 2016

Farr D (2007) Sustainable urbanism: urban design with nature. Wiley, New York

Foxon TJ, Hammond GP, Pearson PJ (2010) Developing transition pathways for a low carbon electricity system in the UK. Technol Forecast Soc Chang 77(8):1203-1213

Freytag T, Gössling S, Mössner S (2014) Living the green city: freiburg's Solarsiedlung between narratives and practices of sustainable urban development. Local Environ 19(6):644-659

Gemeente Breda (1993) Beeld- en milieukwaliteitsplan Westerpark. Gemeente Breda, Breda

Gilmour A, Walkerden G, Scandol J (1999) Adaptive management of the water cycle on the urban fringe: three Australian case studies. Conserv Ecol $3(1): 11$

Girardet H (1996) The GAIA atlas of cities: new directions for sustainable urban living. Gaia Books Limited, London

Gunder M (2011) Fake it until you make it, and then.... Plan Theory 10(3):201-212

Habitat III (2016) Revised zero draft of the new urban agenda. https://www. habitat3.org/zerodraft. Accessed 23 June 2016

HafenCity Hamburg GmbH (2006) HafenCity Hamburg —-the masterplan. HafenCity Hamburg GmbH, Hamburg

Heynen H (1990) Fragmentatie in de periferie: de 'tapijtmetropool'van WillemJan Neutelings. Archis 3:16-21

Howard E (1902) Garden cities of tomorrow. S. Sonnenschein \& Co., Ltd, London

Ikeda S (2004) Urban interventionism and local knowledge. Rev Austrian Econ 17(2-3):247-264

Kauffman SA (1993) The origin of order: self-organisation and selection in evolution. Oxford University Press, New York

Kauffman S (1995) At home in the universe. Oxford University Press, Oxford

Kennedy C, Cuddihy J, Engel-Yan J (2007) The changing metabolism of cities. J Ind Ecol 11(2):43-59

Kennedy C, Pincetl S, Bunje P (2010) The study of urban metabolism and its applications to urban planning and design. Environ Pollut 159(8-9):1965-1973

Kreimer A, Arnold M, Carlin A (eds) (2003) Building safer cities: the future of disaster risk. The International Bank for Reconstruction and Development/The World Bank, Washington

Kriens I, Klaasen IT, Rooij RM (2008) De kern van ruimtelijke planning and strategie. Ruimte en maatschappij. Technische Universiteit Delft, Delft

Kristinsson J (2012) Integrated sustainable design. In: van den Dobbelsteen A (ed). Delft Digital Press, Delft

Lazzaro C (1990) The Italian renaissance garden. From the conventions of planting, design and ornament to the grand gardens of sixteenthcentury central Italy. Yale University Press, London
Lehmann S (2010) Green urbanism: formulating a series of holistic principles. SAPIENS 3(2), Online since 12 October 2010. http://sapiens.revues. org/1057. Accessed 22 June 2016

McHarg IL (1969) Design with nature. Natural History Press, New York

Ministerie van Landbouw, Natuurbeheer en Visserij (1992) Nota landschap. Ministerie van LNV, Den Haag

Mitchell Waldrop M (1992) Complexity. The emerging science at the edge of order and Chaos. Simon and Schuster Paperbacks, New York

Moroni S (2015) Complexity and the inherent limits of explanation and prediction: urban codes for self-organising systems. Plan Theory 14(3):248-267

Neuman M (2005) The compact city fallacy. J Plan Educ Res 25:11-26. doi:10.11 77/0739456X04270466

Newman PWG (1999) Sustainability and cities: extending the metabolism model. Landsc Urban Plan 44:219-226. doi:10.1016/ S0169-2046(99)00009-2

Newman S (2011) Post-anarchism and space: revolutionary fantasies and autonomous zones. Plan Theory 10(4):344-365

Nicholls RJ (1995) Coastal megacities and climate change. GeoJournal 37(3):369-379

Pandis Iverot S, Brandt N (2011) The development of a sustainable urban district in Hammarby Sjöstad, Stockholm, Sweden? Environ Dev Sustain 13(6):1043-1064. doi:10.1007/s10668-011-9304-x

Perry F (2016) Copenhagen's public spaces that turn into picturesque ponds when it rains. The Guardian, 22 January 2016. https://www.theguardian. com/cities/2016/jan/22/copenhagen-flood-public-spaces-turn-intopicturesque-ponds-rains. Accessed 5 Sept 2016

Portugali J (2000) Self-organisation and the city. Springer, Berlin

Portugali J, Meyer H, Stolk E, Tan E (eds) (2012) Complexity theories of cities have come of age: an overview with implications to urban planning and design. Springer Science \& Business Media, Berlin

Priemus H (2007) The network approach: Dutch spatial planning between substratum and infrastructure networks. Eur Plan Stud 15(5):667-686

Prigogine Y, Stengers I (1984) Order out of chaos. Man's new dialogue with nature. Bantam Books Inc, New York

Rittel H, Webber M (1973) Dilemmas in a general theory of planning. Policy Sci 4:155-169 (Reprinted in N. Cross (ed) (1984) Developments in design methodology. Wiley, Chichester, pp 135-144.)

Roggema R (2009) DESIGN, final report hotspot climate proof Groningen. Province of Groningen and Climate Changes Spatial Planning, Groningen

Roggema R (2012a) Swarm planning: the development of a spatial planning methodology to deal with climate adaptation, $\mathrm{PhD}$ thesis. Delft University of Technology, Delft

Roggema R (ed) (2012b) The design charrette: ways to envision sustainable futures. Springer, Heidelberg

Roggema R (2012c) Shifting paradigms. In: Roggema R (ed) The design charrette: ways to envision sustainable futures. Springer, Heidelberg

Roggema R (2014) Towards enhanced resilience in city design: a proposition. Land 3:460-481

Roggema R (2015) Three urbanisms in one city: accommodating the paces of change. J Environ Prot 6:946-956

Roggema R, Broess H (2014a) Darwin in de Ruimtelijke Ordening (1). Groen 70(1):20-24

Roggema R, Broess H (2014b) Darwin in de Ruimtelijke Ordening (2). Groen 70(2):17-22

Roggema R, Martin J, Arcari P, Clune S, Horne R (2013) Design-led decision support process and engagement. VCCCAR, Melbourne

Roggema R, Vos L, Martin J (2014a) Resourcing local communities for climate adaptive designs in Victoria, Australia. Chin J Popul Resour Manag 12(3):210-226. doi:10.1080/10042857.2014.934951

Roggema R, Martin J, Vos L (2014b) Governance of climate adaptation in Australia: design charrettes as creative tool for participatory action research. In: Van Buuren A, Eshuis J, van Vliet M (eds) Action research for climate change adaptation: developing and applying knowledge for governance. Routledge, London, pp 92-108

Russell JS (2011) The agile city. Building well-being and wealth in an era of climate change. Island Press, Washington

Ryan C (2013) Eco-acupuncture: designing and facilitating pathways for urban transformation, for a resilient low-carbon future. J Clean Prod 50:189-199 
Ryan C, Biggs C, Trudgeon M (2013) Eco-acupuncture and greenaissance: designing urban interventions for resilient post-carbonaceous futures, from Victoria (Australia) to Florence (Italy). In: Proceedings of the state of Australian cities conference, 26-29 November 2013, Sydney

Sanders EBN, Stappers PJ (2008) Co-creation and the new landscape of design. Codesign 4(1):5-18. doi:10.1080/15710880701875068

Schwartz A (2013) The 10 cities that are leading the way in urban sustainability. http://www.fastcoexist.com/3016816/the-10-cities-that-are-leadingthe-way-in-urban-sustainability. Accessed 22 June 2016

Searns RM (1995) The evolution of greenways as an adaptive urban landscape form. Landsc Urban Plan 33(1):65-80

Shafiea FA, Dasimah O, Karuppannanb S (2013) Urban metabolism: a research methodology in urban planning and environmental assessment. In: Proceedings of the 1st international conference on research methodology for built environment and engineering Kuala Lumpur, Malaysia, 17-18 December 2013

Sharifi A (2016) From garden city to eco-urbanism: the quest for sustainable neighborhood development. Sustain Cities Soc 20:1-16. doi:10.1016/j. scs.2015.09.002

Sieverts T (1997) Zwischenstadt. Zwischen Ort und Welt, Raum und Zeit, Stadt und Land. Vieweg, Braunschweig

Sijmons D (1992) Het casco-concept, een benaderingswijze voor de landschapsplanning. Ministerie van LNV, directive NBLF, Utrecht

Stive MJF, de Schipper MA, Luijendijk AP, Ranasinghe RWMRJB, van Thiel De Vries JSM, Aarninkhof S, van Gelder-Maas C, de Vries S, Henriquez M, Marx S (2013) The sand engine: a solution for vulnerable deltas in the 21 st century? In: Proceedings coastal dynamics 2013: 7th international conference on coastal dynamics. University of Bordeaux, Arcachon, France, 24-28 June 2013

Sullivan $L$ (1896) The tall office building artistically considered. Lippincott's Monthly Magazine, New York

Surowiecki J (2004) The wisdom of crowds: why the many are smarter than the few. Little Brown, Boston

Taleb NN (2012) Antifragile — things that gain from disorder. Random House, New York

Teeuw P (2010) Duurzame ideeën \% DCBA methodiek: ambitie stellen volgens de viervarianten-methode. AEneas, Boxtel

Tillie N, Klijn O, Frijters E, Borsboom J, Looije M (2014) Urban metabolism Rotterdam. IABR and Municipality of Rotterdam, Rotterdam
Timmermans W, Woestenburg M, Jonkhof J, Annema H, Sllaku M, Yano S (2015) De gewortelde stad-Europese hoofdsteden en hun verbinding met het landschap/the rooted city-European capitals and their connection with the landscape. Uitgeverij Blauwdruk, Wageningen

Tjallingii SP (1995) Ecopolis: strategies for ecologically sound urban development. Backhuys Publishers, Leiden

Tjallingii S (2015) Planning with water and traffic networks. Carrying structures of the urban landscape. Res Urban Ser 3(1):57-80. doi:10.7480/rius.3.832

Tomásek W (1979) Die Stadt als Oekosystem; Überlegungen zum Vorentwurf Landschafsplan Köln (The city as ecosystem; considerations about the scheme of the Landscape design Cologne). Landschaft + Stadt 11:51-60

UN Habitat (2016) Urbanization and development: emerging futures; world cities report 2016. Nairobi, UN Habitat

United Nations (2008) World urbanization prospects. The 2007 revision. Executive summary. United Nations, New York

Urbanisten DE (2013) Water square Benthemplein in Rotterdam, the Netherlands. Landsc Archit Front 1(4):136-143

van Schaick J, Klaasen IT (2011) The Dutch layers approach to spatial planning and design: a fruitful planning tool or a temporary phenomenon? Eur Plan Stud 19(10):1775-1796

Van Timmeren A (2006) Autonomy and heteronomy in the built environment, PhD-thesis. Delft University of Technology, Delft

Van Timmeren A, Sidler D, Kaptein M (2007) Sustainable decentralized energy generation \& sanitation: case EVA Lanxmeer, Culemborg, the Netherlands. J Green Build 2(4):137-150. doi:10.3992/jgb.2.4.137

Vitruvii M (ca. 1480) De Architectura. Napoli

VROM-raad (2007) De hype voorbij, klimaatverandering als structureel ruimtelijk vraagstuk; advies 060. VROM-raad, Den Haag

Waterman RE (2010) Integrated coastal policy via building with nature, PhDthesis. Delft University of Technology, Delft

Webster C, Lai LWC (2003) Property rights, planning and markets. Edward Elgar, Cheltenham

Wise E (2013) A gradual awakening: Broadacre city and a new American agrarianism. Berkeley Plan J 26(1):133-149

Wolman A (1965) The metabolism of cities. Sci Am 213(3):179-190

World Commission on Environment and Development (1987) Our common future. Oxford University Press, Oxford

Wundram M, Pape T (1988) Palladio. Benedikt Taschen VerlagGmbH \& Co. KG, Köln

\section{Submit your manuscript to a SpringerOpen ${ }^{\circ}$ journal and benefit from:}

- Convenient online submission

- Rigorous peer review

- Immediate publication on acceptance

- Open access: articles freely available online

- High visibility within the field

- Retaining the copyright to your article

Submit your next manuscript at $\mathbf{s p r i n g e r o p e n . c o m ~}$ 